Man and Nature

L'homme et la nature

\title{
Thomas Reid's Critique of Joseph Priestley: Context and Chronology
}

Paul B. Wood

Volume 4, 1985

URI : https://id.erudit.org/iderudit/1011835ar

DOI : https://doi.org/10.7202/1011835ar

Aller au sommaire du numéro

Éditeur(s)

Canadian Society for Eighteenth-Century Studies / Société canadienne d'étude du dix-huitième siècle

ISSN

0824-3298 (imprimé)

1927-8810 (numérique)

Découvrir la revue

Citer cet article

Wood, P. B. (1985). Thomas Reid's Critique of Joseph Priestley: Context and Chronology. Man and Nature / L'homme et la nature, 4, 29-45.

https://doi.org/10.7202/1011835ar

Copyright (C) Canadian Society for Eighteenth-Century Studies / Sociéte canadienne d'étude du dix-huitième siècle, 1985
Ce document est protégé par la loi sur le droit d'auteur. L'utilisation des services d'Érudit (y compris la reproduction) est assujettie à sa politique d'utilisation que vous pouvez consulter en ligne.

https://apropos.erudit.org/fr/usagers/politique-dutilisation/ 


\section{Thomas Reid's Critique of Joseph Priestley: Context and Chronology}

Despite its importance, Thomas Reid's response to the series of polemical, philosophical, and theological works published by Joseph Priestley in the 1770s has never received the scholarly attention it deserves. As an active participant in the debates between savants north and south of the Tweed at the turn of the nineteenth century, Reid's disciple and first biographer Dugald Stewart was more anxious to defend common sense philosophy against Priestley's criticisms than to examine Reid's own carefully considered critique of the Dissenter's materialism and necessitarianism. ${ }^{1}$ Later champions of the Scottish philosophical tradition were slightly more dispassionate but scarcely more informative. James McCosh remarked on the care with which Reid prepared his manuscript 'Some Observations on the Modern [i.e. Priestley's] System of Materialism', and McCosh judged the 'Observations' to be 'of a thorough and searching character, distinguished for acuteness beyond almost any of the published writings of Reid, and written with great point and naiveté. ${ }^{2}$ Yet McCosh merely summarized the contents of the manuscript very briefly, and said nothing about its place in Reid's intellectual development at Glasgow. A. Campbell Fraser claimed that Priestley's materialism, as well as Kames' determinism and the teaching duties of the Glasgow chair, prompted Reid to 'carry his reflections onward from the merely physical to the ethical judgments of the common sense, and so upward from the merely natural to the spiritual interpretation of the universe'. ${ }^{3}$ By incorporating the Reid-Priestley episode into his 
narrative, Campbell Fraser thus improved on McCosh, but his interpretation of the significance of this episode reveals more about his own philosophical presuppositions than it does about Reid's later career.

More recently, Selwyn Grave has simply used Priestley's criticisms of Reid, Beattie, and Oswald as a starting point for his exposition of the doctrines of Common Sense philosophy, and he does not pose the obvious historical question as to whether these criticisms had any effect on the Scottish philosophical triumvirate. ${ }^{4}$ J.H. Faurot, on the other hand, has recognized that Priestley's attack did occasion changes in Reid's epistemology. While Faurot's reconstruction is ingenious, it is based on extremely limited evidence, and key documents have been recovered since his study was written. ${ }^{5}$ Reid's response to Joseph Priestley is, therefore, still in need of detailed examination. This paper is intended as a prolegomena to such an examination. Using Reid's manuscripts as well as printed sources, I want to identify the various contexts in which he addressed the problem of materialism, and to establish the chronology of his reaction to Priestley's writings. I shall argue that Reid's perception of, and response to, Priestley's denial of the traditional matter-spirit distinction was conditioned by his earlier encounters with materialism, and that these encounters took place within the contexts of polemics about the nature of man and of particular areas of scientific inquiry like physiology. I shall argue further that, contrary to the claims made by some historians, Reid's reaction to Priestley and hence to David Hartley did not affect the development of his methodology, and that Reid's 'Observations on the Modern System of Materialism' was the product of what was perhaps his last major philosophical endeavour.

As a young mathematician and divine, Reid learned the fundamentals of Newtonian natural philosophy from two main sources: Newton's Principia Mathematica and the works of Samuel Clarke. ${ }^{6}$ While Newton did not directly comment on materialism in the Principia, Clarke had denounced it in his Boyle Lectures, and attacked it in his exchanges with the free-thinker Anthony Collins. Challenging the defence of the immateriality and immortality of the soul given in Clarke's Letter to $\mathrm{Mr}$. Dodwell of 1706, Collins argued that it was not absurd to suppose that thought could be an attribute of matter, and offered two alternative accounts of how this might be possible. First, following Locke, Collins asserted that God could 'superadd' the power of thought to a system of matter in a 'convenient Structure and Disposition'.7 Secondly, Collins 
made the far more radical suggestion that thought is an emergent property of systems of matter. While he agreed with Clarke that individual particles of matter were incapable of thought, he claimed that 'a Man can't turn his Eye but he will meet with Material Systems, wherein there are Individual Powers, which are not in every one, nor in any one of the Particles that compose them when taken apart, and consider'd singly'. ${ }^{8}$ Thus Collins argued that as the particles of matter only have the power of causing a pleasurable sensation in us when they are arranged into a rose, so too matter has the power of thought only when it is organized into the human brain or, as he later implied, when it is formed into animal spirits. ${ }^{9}$

In reply, Clarke denied that systems of matter could have properties not possessed by their parts and that the thinking principle in man could be divisible like matter, and he used Newtonian matter theory and the phenomenon of universal gravitation to prove the existence of active immaterial beings in the natural order. ${ }^{10}$ Reid whole-heartedly subscribed to Clarke's position, ${ }^{11}$ and hence believed that Newtonian natural philosophy was essentially antithetical to heterodox philosophical positions such as materialism. Consequently Reid later responded to Priestley's claim that his theory of matter was sanctioned by Newton's rules of reasoning with a lengthy exposition of those rules in order to demonstrate their incompatibility with Priestley's system of materialism. ${ }^{12}$ Such a response was a legacy of the earlier debates between Newtonian apologists like Clarke and materialists like Collins.

Another author Reid placed in the materialist pantheon was Lord Bolingbroke. ${ }^{13}$ Whether Bolingbroke was, strictly speaking, a materialist is perhaps doubtful, but in his Letters or Essays Addressed to Alexander Pope he used Lockean epistemology to subvert the orthodox matterspirit distinction. According to Bolingbroke, our idea of matter or body is much clearer than that of spirit. He thought that whereas we have reasonably secure and adequate knowledge of the nature of body based on our ideas of sensation, we are almost totally ignorant of the nature of spirit. Sensation informs us that matter has the primary qualities of solidity and extension, while reflection fails to reveal anything about the primary qualities of spirit. ${ }^{14}$ For Bolingbroke the traditional matter-spirit dichotomy was, therefore, epistemologically groundless, a relic of what he called 'the superstitious theology of the heathens'. ${ }^{15}$ Moreover, although Bolingbroke did not categorically deny the existence of spirit, and in particular the existence of an omnipotent spirit, he did accept Locke's thesis that God could 'superadd' the power of thought to matter. Commenting on William Wollaston's criticisms of Locke's view, Bolingbroke wrote that ' $\mathrm{He}$, who says that the power of thinking is a faculty, 
superadded by the Creator to certain systems of matter ... assumes [an hypothesis] indeed, but he assumes [it] conformably to the phaenomena'. By contrast, Bolingbroke believed that religious apologists like Wollaston assumed an hypothesis 'without any support from the phaenomena, nay even in an apparent contradiction to them'. ${ }^{16}$ Bolingbroke thus stressed the plausibility of materialism without actually commiting himself explicitly to it. Reid ignored Bolingbroke's disclaimers, however, and concentrated on the Englishman's endorsement of Locke's highly controversial speculation.

Reid was also familiar to some extent with the polite materialism of the fashionable French salons. In his Glasgow lectures on the 'Culture of the Human Mind' delivered in the mid-1760s, Reid cited Helvétius' infamous De l'espirit (1758), but it is uncertain whether he subsequently knew at firsthand Helvétius' posthumous De l'homme (1770). ${ }^{17}$ When it appeared in 1758, De l'esprit was, as is well known, a great succès de scandale, and Helvétius was roundly condemned as an atheist, materialist, and necessitarian. ${ }^{18}$ The charge of materialism rested largely on a brief passage in which Helvétius discussed the ambiguity of the word 'matter', and concluded that it was an empirical question as to whether matter was sentient, thereby dismissing at a stroke the a priori arguments of metaphysicians such as Clarke. ${ }^{19}$ Yet Helvétius did not here claim that matter was in fact capable of thought nor did he explicitly deny the existence of spirit. ${ }^{20}$ Like Bolingbroke, therefore, Helvétius was perceived as a materialist because he questioned the matter-spirit distinction as drawn by defenders of orthodoxy, rather than because he made any unequivocal statement of a thorough-going materialist conception of man. Reid certainly shared this popular perception of philosophes like Helvétius. Writing to Lord Kames in 1778, he remarked: 'I am not much surprised that your Lordship has found little Entertainment in a late French Writer on Human Nature. From what I learn they are all become rank Epicureans'.21

From a passage in his natural theology lectures given in the 1779-1780 session, it appears that Reid was also acquainted with Baron d'Holbach's notorious Système de la Nature (1770). ${ }^{22}$ In the Système, d'Holbach made no pretence of concealing his militant materialism and atheism. He rejected the orthodox view that matter is inert, and claimed instead that the essence of matter was to act. Consequently d'Holbach denied that a valid distinction could be drawn between living and dead powers, and asserted that inertia or the vis insita was not a truly passive power. ${ }^{23}$ Furthermore, he cited John Turberville Needham's experiments on equivocal generation to prove that animate matter could be produced from inanimate matter. Thus life was, for $\mathrm{d}^{\prime} \mathrm{Holbach}$, a function of the organiza- 
tion of matter rather than the operation of immaterial agents impressed on otherwise inert material systems. ${ }^{24}$ Regarding the nature of man, d'Holbach maintained that man was nothing more than a material being organized in a particular way and subject to the laws of nature. The idea of an immaterial soul was an imaginary fiction of recent historical origin, and the notions of free will and immortality were similarly delusory. So too was our notion of God. D'Holbach argued that our concept of the Divine Being was the product of our ignorance of the laws governing the natural order, and that the term 'God' was used to refer to the unknown causes of the phenomena of nature. ${ }^{25} \mathrm{He}$ then went on to attack the proofs of the existence of God which had been offered by Clarke, Descartes, Malebranche, and Newton, and he concluded the Système with an apologia for atheism. ${ }^{26}$ In d'Holbach's view, therefore, both man and nature were simply the products of matter in motion.

Prior to his reading of Priestley, then, Reid confronted materialism in this general context of pamphlet polemics and heterodox speculation on the nature of man, in which materialism was bound up with Deism, atheism, and aggressive anti-clericalism. Seen against this background, Priestley's attempted reconciliation of materialism and Christianity must have seemed utterly incongruous to Reid.

\section{II}

Within more specific contexts of scientific research, Reid grappled with theories of generation and of human physiology which to him were either overtly materialist or had materialistic implications. Mechanical accounts of generation, like that given in Descartes' posthumously published De la formation de l'animal (1664), inevitably gave rise to accusations of materialism, and they were indeed adopted by materialists such as Anthony Collins. In his exchanges with Clarke, Collins asserted that matter was capable of organizing itself into an embryo within the egg by motion alone. He wrote:

I see no absurdity in supposing the organiz'd Body of the Animal to be form'd by Mechanical Motions out of such Matter as the unorganiz'd parts of an Egg, if they may be call'd unorganiz'd: Those Parts are not indeed Legs, Wings, Eyes \&c. and so are not organiz'd in that sense; but yet they are so dispos'd or organiz'd as to contribute by their motion towards something orderly and regular, and to become parts of the Leg or the Eye of an Animal.27

Reid and his fellow members of a philosophical club active in Aberdeen 
in the mid-1730s probably had such explanations in mind when, on 12 January 1736, they discussed the question 'What things in the Course of Nature we may reasonably ascribe to the continual influence \& Operation of God or other active powers and Invisible beings under him?', for they concluded that in generation some kind of active power or powers exercised 'A Continual Influence'. ${ }^{28}$

The subject of generation reappears in Reid's manuscripts some sixteen years later with reference to his teaching responsibilities at King's College Aberdeen. In a manuscript entitled 'Scheme of a Course of Philosophy' drawn up in 1752, Reid made provision for lecturing on the generation of animals, and it would seem that he did in fact do so following the restructuring of the curriculum at King's in $1753 .{ }^{29}$ Unfortunately the texts of his lectures have not survived, but we do know that he included materials from the works of Hooke, Leeuwenhoeck, Reamur, Swammerdam, and the English microscopist Henry Baker. ${ }^{30}$ In addition, Reid may have incorporated some of the findings of Buffon, as he took careful notes summarizing the essentials of the controversial epigenetic explanation of generation propounded in the second volume of Buffon's Histoire Naturelle. ${ }^{31}$ However, it is highly unlikely that Reid endorsed Buffon's theory in his lectures, since he believed that the Frenchman had attributed too many powers to matter, and thereby encouraged materialist explanations of generation. ${ }^{32}$ Reid also denied the validity of theories which purported to explain generation in terms of the attractive and repulsive forces associated with brute matter. One such reductionist theory which had gained notoriety was that propounded by Maupertuis in his Venus Physique of 1745. Here Maupertuis invoked attractive forces akin to the elective affinities postulated by the chemist Geoffroy to account for the formation of the embryo in animals. ${ }^{33}$ Reid opposed this kind of reductionist Newtonianism, and he distinguished sharply in his prelections between the powers possessed by unorganized and organized bodies. ${ }^{34}$ More generally, Reid could not accept that matter endowed with either a vegetative or an attractive force had the capacity to form organized vegetable and animal bodies de novo as Buffon and Maupertuis had claimed, because this detracted from God's providential activity in the natural order and hence in Reid's eyes countenanced materialism.

During the 1750s Reid confronted the problem of spontaneous or equivocal generation as well, for on 28 June 1758 the members of the Aberdeen Philosophical Society discussed the question posed by George Campbell, 'Can the generation of worms in the bodies of animals be accounted for on the common principles of generation?'. ${ }^{35}$ Since the end of the seventeenth century, it had been widely recognized that the generation of intestinal parasitic worms could not be easily reconciled with the 
principles of preformationism. Buffon and his collaborator John Turberville Needham, on the other hand, argued that the generation of such parasites could be fully explained by the theory which they advocated, and materialists cited the phenomena of equivocal generation to prove that matter was capable of reproducing and organizing itself without the supervention of immaterial causes. ${ }^{36}$ Issues such as these probably inspired Campbell's question, and we can see from the versions of the abstract of the question which have survived that Campbell and his colleagues endeavoured to account for the anomalous phenomena of equivocal generation in preformationist terms. ${ }^{37}$ Reid would no doubt have denied that parasitic worms were produced spontaneously, for this implied that new organisms were being continually created in nature. If this creative process were ascribed to natural causes, then the theory of spontaneous generation appeared to derogate God's omnipotence and to sanction materialism. Moreover, being a preformationist, Reid may have held that at the Creation God had formed the total supply of 'organized atoms' which were later to mature into plants and animals. Consequently there was no need for God to arbitrarily intervene in nature in order to make random parcels of matter vital. ${ }^{38}$

Although Reid was no longer obliged to prelect on the theory of generation after taking up the Glasgow chair of Moral Philosophy in 1764, he nevertheless chose to consider the subject briefly in his lectures. From the set of student notes on natural theology taken in the 1766-1767 session, we can see that Reid reviewed some of the general facts about the propagation of vegetables and animals, emphasized the wisdom and design illustrated by these facts, endorsed the principles of preformation, and denounced the folly of materialism. ${ }^{39}$ As a Glasgow Professor, then, Reid continued to attack materialism within the context of generation.

While at King's College Aberdeen, Reid also lectured on muscular motion. Following the curriculum reforms of 1753, he apparently included in his natural history course three lectures based on Robert Whytt's Essay on the Vital and other Involuntary Motions in Animals (1751). These lectures were intended to demonstrate that 'The Origin of Motion in the human Body ... is not mechanical'. ${ }^{40}$ Whytt's Essay well-suited this aim, for Whytt there argued that,

the human body ought not to be regarded (as it has too long been by many physiologists) as a mechanical machine, so exquisitely formed, as, by the mere force of its construction, to be able to perform, and continue the several vital motions; actions far above the powers of mechanism! But as a system, framed indeed with the greatest art and contrivance ... yet a system whose functions are all owing to the power and agency of an immaterial sentient principle to 
which it is united, and by which every part of it is animated and put in motion. ${ }^{41}$

Whytt criticized iatro-mechanists, Cartesians, and materialists alike for conceiving of the human body as a mere machine, and it is likely that it was his intense anti-mechanism and anti-materialism which recommended Whytt's physiology to Reid. ${ }^{42}$ In addition, Reid would no doubt have approved of the Newtonian conceptual framework of the Essay, and Whytt's emulation of Newton's cautious inductivism, antihypotheticalism, and avoidance of undue speculation about efficient causes. ${ }^{43}$ Finally, Reid would have agreed entirely with Whytt's conclusion that 'true physiology' both proves the existence of the soul, and 'leads us up to the first cause and Supreme Author of all'. ${ }^{44}$ It was probably for reasons such as these that Reid declared Whytt's theory of muscular irritability 'the most probable Hypothesis yet advanced on [the involuntary motions of animals] \& I think the onely one that deserves examination'.45

As part of his study of the human senses and his critique of the theory of ideas, Reid was also interested in the physiology of perception during his years at King's College, if not before. The significance of his work on this subject is two-fold. First, Reid's attack on hypotheses as published in the Inquiry was addressed in part to physiological theories which assumed the existence of animal spirits or elastic ethers, or the capacity of the nerves to vibrate like the strings of a musical instrument. Foreshadowing his later criticisms of Hartley, Reid wrote in the Inquiry:

how can the images of sound, taste, smell, colour, figure, and all the sensible qualities be made out of the vibrations of musical chords, or the undulations of animal spirits, or of ether? We ought not to suppose means inadequate to the end. ${ }^{46}$

After moving to Glasgow, he continued to dismiss these theories as mere hypotheses in his lectures, and by 1769 he had formulated his own distinctive interpretation of Newton's First Rule of Philosophizing, a point to which I shall return in a moment. ${ }^{47}$ Reid's anti-hypotheticalism, therefore, evolved in the context of his review of the physiological mechanisms used to explain the physical basis of human perception in the first half of the eighteenth century.

Secondly, Reid's criticisms of these mechanisms are symptomatic of a more general reaction against the mechanistic and reductionist mode of physiological theorizing popular in the period prior to $c .1750 .{ }^{48}$ Robert Whytt was one of the first physiologists in Britain to reject ethers and 
animal spirits, and to question whether the phenomena of the human body were explicable in terms of the attractive and repulsive forces active in the inanimate realm of nature. Similarly, Reid assailed the standard explanatory concepts of the physiologists' theoretical repertoire, and asserted that in the vegetable and animal kingdoms, there are strong indications of powers of a different nature from all the powers of unorganized bodies'. ${ }^{49}$ Thus Reid's assault on nervous ethers and fluids and his opposition to reductionism reflect broader theoretical and methodological shifts within the science of physiology, as well as trends in eighteenth-century natural philosophy more generally..$^{50}$ His dislike of ethers and fluids and of reductionism also reflects, I suggest, his antipathy towards the mechanistic and materialistic models of man fostered by the dominant mode of physiological theorizing earlier in the century.

III

Having identified and described the contexts of Reid's reaction to Joseph Priestley, let me briefly reconstruct the chronology of that reaction. While the two men were acquainted with each other's writings by the late 1760s, they did not come into conflict until 1774, when Priestley announced in the Introduction to the third part of his Institutes of Natural and Revealed Religion that he planned to publish a critical review of what he called the 'ill-founded and dangerous' principles advanced by Oswald, Beattie, and Reid.51 On 28 April 1774, Priestley sent advance copies of this introduction to each of the Scottish savants, accompanied by a letter giving personal notice of his intentions. ${ }^{52}$ Oswald and Beattie acknowledged Priestley's communication, but Reid refrained from replying. ${ }^{53}$ Prompted by the letter, however, he looked through the first two volumes of Priestley's Institutes on 18 June, and, as his reading notes show, he was unimpressed by the Dissenter's performance. Passages on the capacity of matter to think and on common sense caught his eye, as did Priestley's analysis of human action, but he dismissed both volumes for their lack of distinct reasoning and philosophical precision. ${ }^{54}$ Following up Priestley's glowing references to David Hartley, Reid read Hartley's Observations on Man the next day, and made an extensive summary of a number of propositions from Part One, Chapters I and III, dealing with the correlation between vibrations in the brain and ideas in the mind, and with the hypothetical method. ${ }^{55}$ We see, then, that Reid had formulated his methodological doctrines, and in particular his antihypotheticalism, prior to his reading of Hartley. Consequently, it is incorrect to suggest, as does Larry Laudan, that Reid's inductivism and 
anti-hypotheticalism evolved as a response to Hartley's advocacy of the method of hypotheses and of an etherial physiology. ${ }^{56}$ Rather, Reid's methodology developed within the context of his critique of Hume and the theory of ideas and of the physiological theories current in the first half of the eighteenth century. The writings of Hartley and Priestley certainly elicited significant restatements of Reid's methodological views, but they did not precipitate any important revision or reformulation.

Priestley's Examination of Reid, Beattie, and Oswald duly appeared in the late summer of 1774, and he presented each of them with a copy of the work. ${ }^{57}$ For his part, Reid discussed the Examination with his Glasgow colleagues and followed the reviews and correspondence about it in periodicals such as the London Chronicle, but he remained silent publicly. ${ }^{58}$ As he later wrote to Richard Price: 'I had resolved from the beginning ... to give him [Priestley] no Disturbance'. In this letter, Reid also said of his opponent: 'I confess that in his late Examination \&c he seems to me very lame in Abstract Reasoning as well as in some other qualities of more Estimation. I have got no Light from him to attone for his Abuse'. ${ }^{59}$ Reid did not subsequently alter this assessment of Priestley's philosophical talents, nor did he ever forgive him for the insults and obloquy contained in the Examination.

In 1775 Priestley published his Hartley's Theory of the Human Mind, wherein he suggested that all of man's mental powers arose from the 'organical structure' of the brain. Like Collins before him, Priestley stressed that he argued 'only for the bare possibility' that matter was capable of sustaining thought, and he too appealed to the authority of Locke in order to legitimate his speculations. ${ }^{60}$ Roused by this materialist interpretation of Hartley, Reid prepared a lengthy manuscript entitled Miscelaneous [sic] reflections on Priestly's [sic] account of Hartley's theory of the human mind', in which he attacked Priestley's materialism, epistemology, and editing practice. ${ }^{61}$ Priestley's edition of Hartley may also have motivated Reid to include criticisms of their work in his lectures on the mind, criticisms which only appear in his lectures in the late 1770 s. ${ }^{62}$

Unfortunately the chronology of subsequent events becomes increasingly difficult to establish, since few of the relevant manuscripts are dated, and the minutes of the Glasgow Literary Society for the years 1779 to 1794 are no longer extant. Reid probably read Priestley's Disquisitions Relating to Matter and Spirit (1777) and the exchanges between Priestley and Price published as A Free Discussion of the Doctrines of Materialism and Philosophical Necessity (1778) shortly after they appeared, and he seems to have kept up with reviews of Priestley's works. ${ }^{63}$ Following his retirement from active teaching in 1780 , Reid was mainly 
occupied with preparing his lectures for the press, and in this period he formulated the replies to Priestley's criticisms of the Inquiry and the objections to the Dissenter's necessitarianism which appeared in the two Essays. What little evidence there is indicates that Reid delivered three discourses on Priestley's materialism to the Glasgow Literary Society in the early 1780s which he later revised to form 'Some Observations on the Modern System of Materialism'. Then, at the end of the decade, it seems that he gave two final discourses related to Priestley's matter theory, before turning his attention to other topics. Reid's 'Observations' were thus the product of the twilight of his career. ${ }^{64}$

\section{IV}

To conclude on a more speculative note, I want to explore possible reasons why Priestley chose to criticize Reid, Beattie, and Oswald when he did. In the period in which Priestley published his Institutes and prepared the Examination, London Dissenting ministers seeking relief from subscribing to the Thirty-Nine Articles were petitioning Parliament to alter the Toleration Act of 1689. Although Priestley was not directly involved in the Dissenters' deliberations until 1775, his support for the cause was well known. ${ }^{65}$ The years 1770 to 1773 saw James Beattie rise to fashion among the literati of London, his Essay on Truth gaining him a state pension from George III. ${ }^{66}$ Moreover, circumstantial evidence suggests that Reid's Inquiry was enjoying wide currency in the metropolis and elsewhere. ${ }^{67}$ These seemingly unrelated facts are, I would argue, connected, and partly explain why Priestley launched his attack on the Scottish savants. As the Examination makes abundantly clear, Priestley believed that the appeal to common sense was antithetical to rational religion, and he was disturbed by the popularity which the works of the Scottish authors then enjoyed. Taken in conjunction, these points suggest that Priestley feared that if common sense philosophy were to gain widespread acceptance, especially at Court, then the Dissenters' campaign for relief from subscription would be endangered. An epistemology which (to him) celebrated subjective sentiments and feelings as the ultimate standards of truth could, he seems to have thought, be used to sanction the most arbitrary principles and policies. Consider the following passage from the Examination which states these themes explicitly:

Dr Oswald's treatise ... as well as Dr. Beattie's, has many admirers, both north and south of the Tweed. 
Finding things in this situation, I own I was willing to interpose my feeble endeavours to put a stop to this sudden torrent of nonsense and abuse that is pouring down upon us from the North ... if this task should not be undertaken ... I am afraid we shall find these new principles [of common sense] extending their authority farther than the precincts of metaphysics, morals, religion, Christianity and Protestanism, to which they have been hitherto confined. Papists may begin to avail themselves of them for the support of all those doctrines ... for which the powers of reason had proved insufficient; and politicians also, possessing themselves of this advantage, may venture once more to thunder out upon us their exploded doctrines of passive obedience and nonresistance. For having now nothing to fear from the powers of reason, and being encouraged by the example of grave divines and metaphysicians, they may venture to assert their favourite maxims with the greatest confidence; appealing at once to this ultimate tribunal of common sense, and giving out their own mandates as the decisions of this new tribunal. ${ }^{68}$

Remarks such as these indicate that more than mere intellectual disagreement motivated Priestley to write the Examination. Once we look at the particular historical conjuncture at which he did so, we can see that his motivation was largely to further the political cause of Dissent by refuting a potentially dangerous philosophical resource for its opponents. It was primarily for this reason, I believe, that in the years 1773 and 1774 Rational Dissent came into conflict with Scottish Common Sense.

\section{P.B. WOOD}

Institute for the History and Philosophy of Science and Technology, University of Toronto

\section{Notes}

The author wishes to thank the Librarians of Aberdeen University and the Mitchell Library Glasgow for permission to quote from manuscripts in their keeping, and Dr. G.N. Cantor and an anonymous referee for their comments on earlier drafts of this paper. Some of the points discussed here are developed in more detail in my Thomas Reid, Natural Philosopher: A Study of Science and Philosophy in the Scottish Enlightenment', (unpublished Ph.D. dissertation, University of Leeds, 1984). The present paper was also written prior to the appearance of John W. Yolton's important study, Thinking Matter: Materialism in Eighteenth-Century Britain (Minneapolis, 1983). 
1 Dugald Stewart, Account of the Life and Writings of Thomas Reid, D.D. F.R.S. Edin. Late Professor of Moral Philosophy in the University of Glasgow (Edinburgh, 1803), especially pp. 94-164.

2 James McCosh, The Scottish Philosophy, Biographical, Expository, Critical, From Hutcheson to Hamilton (London, 1875), pp. 206, 473.

3 A. Campbell Fraser, Thomas Reid (London and Edinburgh, n.d.), p. 100.

4 S.A. Grave, The Scottish Philosophy of Common Sense (Oxford, 1960), chapters I and IV. Grave does note on page 206 that Priestley became the main target of Reid's attack on necessitarianism.

5 J.H. Faurot, 'Reid's Answer to Joseph Priestley', Journal of the History of Ideas, 39, (1978), 285-92. The manuscript 'Of Constitution' with which Faurot is concerned in this article was given to the Aberdeen University Library (hereinafter referred to as AUL) in 1980; see AUL, MS 3061/8.

6 Dated reading notes taken from Newton's Principia in October 1729 survive among Reid's papers, as do extensive notes from the works of Samuel Clarke apparently made in the 1730s; see AUL, MSS 2131/7/III/15 and 3/II/7-8.

7 Anthony Collins, A Letter to the Learned Mr. Henry Dodwell; Containing Some Remarks on a (pretended) Demonstration of the Immateriality and Natural Immortality of the Soul, in Mr. Clark's Answer to his late Epistolary Discourse \&c., second edition, corrected (London, 1709), pp. 10-11. For Locke see An Essay Concerning Humane Understanding (London, 1690; Menston, 1970), IV.3.vi.

8 Collins, Letter, p. 11.

9 Collins, Letter, pp. 11-12; [Anthony Collins], An Answer to Mr. Clark's Third Defence of his Letter to Mr. Dodwell, second edition, corrected (London, 1711), pp. 31, 36.

10 Samuel Clarke, The Works of Samuel Clarke, D.D. Late Rector of St. James's Westminster, 4 vols (London, 1738), III, 759-62, 849. In the second passage cited Clarke gives a very clear statement of the matter-in-a-nutshell theory. On some of Clarke's arguments see R. Attfield, 'Clarke, Collins and Compounds', Journal of the History of Philosophy, 15 (1977), 45-54.

11 Reid probably read the Clarke-Collins exchanges when Clarke's Works were published in 1738, if not before. The first explicit reference to the Clarke-Collins debate which $I$ have found in his papers comes in a manuscript related to his pneumatology lectures which appears to date from the 1760s; see AUL, MS 2131/4/II/4, fol. 1r. Reid outlined this debate in his natural theology lectures as well; see George Baird, 'Notes From the Lectures of Dr Thomas Reid', The Mitchell Library Glasgow, MS A104929, 8 vols, IV, lecture 71 (this volume is not paginated). Reid also knew the satire of Clarke and Collins written by the Scriblerians; see Baird, IV, lecture 71, and AUL, MS 2131/4/II/4, fol. 1r. For the satire see C. Kerby-Miller, Memoirs of the Extraordinary Life, Works, and Discoveries of Martinus Scriblerus (New Haven, 1950), pp. 138-42. I should like to thank Dr. J.C. Stewart-Robertson for this reference.

12 The Theological and Miscellaneous Works, Ec. of Joseph Priestley, edited by J.T. Rutt, 25 vols (London, 1817-32), III, 202; AUL, MS 3061/1/4, pp. 12-23 (original pagination). 
13 See Baird, IV, lecture 71. It is uncertain when Reid first read Bolingbroke's philosophical works.

14 Lord Bolingbroke, The Philosophical Works of the Late Right Honourable Henry St. John, Lord Viscount Bolingbroke, 5 vols (London, 1754; Geneva, 1968), I, 207-11.

15 Bolingbroke, Works, I, 218, note. One wonders whether Reid perceived the parallel between Bolingbroke's dismissal of the traditional conception of the soul as a heathen relic, and Priestley's historical account of the origins of the popular and philosophical concepts of the soul in the Disquisitions; see Priestley, Works, III, 351-73, 384-446.

16 Bolingbroke, Works, I, p. 214, note.

17 AUL, MS 2131/4/1/29, p. 16 (original pagination).

18 D.W. Smith, Helvétius: A Study in Persecution (Oxford, 1965), passim.

19 Claude Adrien Helvétius, Oeuvres Completes d'Helvétius, edited by La Roche, 14 vols (Paris, 1795; Hildesheim, 1969), I, 262-65.

20 This point has recently been stressed by Alan Kors in his D'Holbach's Coterie: An Enlightenment in Paris (Princeton, 1976), pp. 56-57.

21 Reid to Lord Kames, 27 February 1778, in Ian Ross, 'Unpublished Letters of Thomas Reid to Lord Kames, 1762-1782', Texas Studies in Literature and Language: A Journal of the Humanities, 7 (1965), 17-65 (p. 31). One source for Reid's knowledge of the French materialists was probably George Jardine, who met Helvétius while in Paris during the period 1770 to 1773; see DNB, $\mathrm{X}, 687$. Jardine may also have met d'Holbach through Hume's contacts in Paris; see Kors, D'Holbach's Coterie, pp. 108-9.

22 Baird, V, 102 (original pagination).

23 Paul-Henry Th. d'Holbach, Système de la Nature: ou des lois du monde physique et $d u$ monde moral, edited by Yvon Belavel, 2 vols (Paris, 1821; Hildesheim, 1966), I, 20-25. D'Holbach cites Toland's Letters to Serena on page 21.

24 D'Holbach, Système, I, 27. For Needham's reaction to d'Holbach's reference see Shirley A. Roe, 'John Turberville Needham and the Generation of Living Organisms', Isis, 74 (1983), 159-5 (pp. 175-76).

25 D'Holbach, Système, I, 108-23, 223-67, 305-42, 439-68.

26 D'Holbach, Système, II, 39-129, 312-423.

27 [Anthony Collins], Reflections on Mr. Clark's Second Defence of His Letter to Mr. Dodwell, second edition, corrected (London, 1711), p. 25.

28 AUL, MS 2131/6/1/17, fol. 1r. Reid and his associates here echo Samuel Clarke; see The Leibniz-Clarke Correspondence, edited by H.G. Alexander (Manchester, 1956), p. 117. Reid was carefully reading through the Leibniz-Clarke exchanges at this time.

29 AUL, MSS 2131/8/V/1, fol. 1v, and 7/II/17, fol. $1 \mathrm{r}$.

30 AUL, MSS 2131/8/V/1, fol. 1v, and 7/II/17, fol. 1r. 
31 AUL, MSS 2131/3/II/14, fols 2r-3r, and 6/V/12, which is entitled 'Experiments upon Seminal Liquors'. Both of these manuscripts seem to date from the 1750 s.

32 While Reid did not think that Buffon was a materialist, he certainly regarded the Frenchman as a heterodox thinker like Helvétius; see AUL, MSS 3061/9, p. 1 (original pagination) and 2131/4/1/29, pp. 16-17 (original pagination). See also Reid's Essays on the Intellectual Powers of Man (Edinburgh, 1785; Menston, n.d.), p. 631, where Reid notes that like Descartes, Buffon had rejected final causes.

33 Pierre-Louis Moreau de Maupertuis, The Earthly Venus, translated by S.B. Boas (New York and London, 1966), pp. 54-56. On Maupertuis's theory of generation see Jacques Roger, Les Sciences de la Vie dans la Pensée Française du XVIIIe Siècle: La Génération des Animaux de Descartes a l'Encyclopédie, $2^{\mathrm{e}}$ ed. (Paris, 1971), pp. 474-81 (pp. 477-78).

34 AUL, MS 2131/6/V/34, fol. 1r; see also 6/V/9-10.

35 McCosh, Scottish Philosophy, p. 467.

36 John Farley, The Spontaneous Generation Controversy from Descartes to Oparin (Baltimore and London, 1977), pp. 18-29; Aram Vartanian, Diderot and Descartes: A Study of Scientific Naturalism in the Enlightenment (Princeton, 1953), pp. 258-62; Roe, 'John Turberville Needham', pp. 171-74.

37 AUL, MS 37, fol. 188r-v, and MS 475, pp. 284-89 (original pagination). The experiments performed by Buffon and Needham on equivocal generation are cited in MS 37, fol. 188r.

38 I assume here that in the 1750s Reid accepted the standard preformationist view that God formed the organized atoms at the creation. However, in the 1770 s he believed there was no evidence to support this.

39 AUL, MS 2131/8/VII, pp. 65-68 (original pagination).

40 AUL, MS 2131/7/II/17, fol. 1r; see also his 'Scheme of a Course of Philosophy', AUL, MS 2131/8/V/1, fol. 1v, where Reid lists The Muscles and Organs of Voluntary Motion' as a lecture subject.

41 Robert Whytt, The Works of Robert Whytt, M.D. (Edinburgh, 1768), p. 171.

42 Whytt, Works, pp. 98, 110, 142-43, 145, 147-48, 153.

43 Whytt, Works, pp. v-vi, 2, 6, 31, 152, 172.

44 Whytt, Works, p. 208.

45 'Of the Involuntary Motions of Animals', AUL, MS 2131/7/II/2, fol. 1r. This manuscript almost certainly dates from the 1750s.

46 Thomas Reid, An Inquiry into the Human Mind, edited by Timothy J. Duggan (Chicago and London, 1970), p. 199.

47 AUL, MS 2131/4/II/2, insert, p. 5 (original pagination).

48 R.E. Schofield, Mechanism and Materialism: British Natural Philosophy in an Age of Reason (Princeton, 1970), chapter IX; T.M. Brown, 'From Mechanism to Vitalism in Eighteenth-Century English Physiology', Journal of the History of Biology, 7 (1974), 179-216. 
49 Reid, Inquiry, p. 263.

50 Reid opposed reductionism in chemistry as well, following the example of Cullen and others; on Cullen's anti-reductionism see Arthur L. Donovan, Philosophical Chemistry in the Scottish Enlightenment: The Doctrines and Discoveries of William Cullen and Joseph Black (Edinburgh, 1975), pp. 98-102.

51 Priestley, Works, II, 250. Priestley read Reid's Inquiry soon after it was published and later referred to it in his History and Present State of Discoveries relating to Vision, Light, and Colours (London, 1772; Millwood, N.Y., 1978), pp. 658, 665; see also Priestley, Works, III, 4. In August 1768 Reid read Priestley's History and Present State of Electricity (1767); see AUL, MS 2131/3/I/9.

52 Priestley, Works, III, 157. See also Priestley to Caleb Rotherham, 31 May 1774 in A Scientific Autobiography of Joseph Priestley, 1733-1804: Selected Scientific Correspondence, With Commentary, edited by R.E. Schofield (Cambridge, Mass., and London, 1966), pp. 145-46.

53 Priestley, Works, III, 157-66.

54 AUL, MS 2131/3/I/25, fol. 1r-v.

55 AUL, MS 2131/3/I/25, fols 1v-3r. Reid refers in his notes to propositions i, ii, vi, vii, viii, ix, x, xii, and xiv, especially corollary 10 on intellectual pleasures and pains.

56 Larry Laudan, 'The Medium and Its Message: A Study of Some Philosophical Controversies about Ether', in Conceptions of Ether: Studies in the History of Ether Theories 1740-1900, edited by G.N. Cantor and M.J.S. Hodge (Cambridge, 1981), pp. $157-85$ (p. 171).

Although it could be argued that it is still possible that Reid read Hartley prior to 1774 , none of the extant evidence suggests this. I have not found a single reference to Hartley in any of Reid's papers or in the student lecture notes which date from before 1774. Even if we admit that Reid may have read Hartley in the 1750 s or 1760 s, the evidence still indicates that he only seriously engaged with Hartley's Observations after reading Priestley. It should also be remembered that Priestley was largely instrumental in popularizing Hartley's work, so that there is no reason to believe that Reid would necessarily have come across it. The Observations did not reach a second edition until 1791, while Priestley's version appeared in a second edition in 1790 .

57 Priestley, Works, III, 3.

58 For an extensive undated abstract of the Examination see AUL, MS 3061/15. In an undated letter to Richard Price, Reid mentioned discussions with his Glasgow associates concerning Priestley's work, and the correspondence about it in the London Chronicle; Reid to Price, undated, AUL, MS 2131/3/III/5, fols 1r-2v (fol. $2 \mathrm{r}-\mathrm{v}$ ). For the correspondence on the Examination see the London Chronicle, 36 (1774), pp. 425, 532.

59 Reid to Price, undated, AUL, MS 2131/3/III/5, fols $1 r-2 v$ (fol. 2r). Priestley later regretted the tone of the Examination; see the Autobiography of Joseph Priestley, edited by Jack Lindsay (Bath, 1970), p. 113.

60 Priestley, Works, III, 180-82.

61 AUL, MS 3061/9. 
62 Baird, I, 39-42 (original pagination). Baird's notes were taken in the 1779-1780 session.

63 Reid referred to the Disquisitions in his natural theology lectures for 1779-1780; see Baird, IV, lecture 71. Two sets of reading notes from the Disquisitions survive, one undated and the other from May 1788; AUL, MSS 3061/12, fol. 2v; and 3061/14. AUL, MS 3061/13 is an undated set of notes from the Free Discussion. A review of the Free Discussion was brought to Reid's attention by his colleague Robert Findlay; see AUL, MS 2131/3/III/22, fol. 1v.

64 Part of the draft of the third of the first set of discourses survives, and Reid there summarizes what he had already said to the Society; AUL, MS 3061/23, fols $2 \mathrm{r}-3 \mathrm{v}$. The undated reading note from the Disquisitions referred to in note 63 is to be found with a discussion of Butler from 1781, and this suggests that the group of three discourses on Priestley was read in the early 1780s. From 1784 to 1786 Reid delivered discourses on free will and necessity, and it is likely that his last two discourses related to Priestley's materialism were given soon after, especially since the dated notes from the Disquisitions come from 1788; AUL, MS $3061 / 22$, fol. $2 \mathrm{v}$. Reid probably then revised his earlier discourses to form the 'Observations'.

65 On this episode see John Stephens, 'The London Ministers and Subscription, 1772-1779', Enlightenment and Dissent, 1 (1982), 43-71.

66 Beattie's success is chronicled in Sir William Forbes, An Account of the Life and Writings of James Beattie, LL.D. (London, 1824), pp. 144-61.

67 On the popularity of the Inquiry see Bennet Langton to James Boswell, 17 June 1773, in The Correspondence of James Boswell with Certain Members of the Club, edited by C.N. Fifer (London, 1976), p. 30. Moreover, the Inquiry had gone through three editions by 1770 .

68 Priestley, Works, III, 101-2. 